\title{
Forest conditions and management under rapid legislation change in Romania
}

\author{
by Bogdan M. Strimbu ${ }^{1,2}$, Gordon M. Hickey ${ }^{1}$ and Vladimir G. Strimbu ${ }^{3}$
}

\begin{abstract}
This paper evaluates the effects of post-communist economic transition on forest resources in Romania. Using data from 1993 and 2003, our research describes a sample of forested landscape units based on seven environmental attributes. These attributes were then compared to four technical attributes associated with forest management planning. The comparative analysis revealed that many forest stand attributes were significantly affected between 1993 and 2003, potentially by the forest ownership change, while most of the forest management attributes were not. Our results suggest that a dramatic change in forestry legislation does not necessarily result in a dramatic change in the descriptive characteristics of forest resources in that jurisdiction but, rather, in the structure of the forest.
\end{abstract}

Key words: economic transition, Eastern Europe, forestry, policy, non-parametric statistics

\section{RÉSUMÉ}

Cet article évalue les effets de la transition économique post-communiste sur les ressources forestières de la Roumanie. À partir des données de 1993 et de 2003, nos recherches décrivent un échantillon des unités du paysage forestier selon sept caractéristiques environnementales. Ces caractéristiques ont été comparées par la suite à quatre caractéristiques techniques associées à la planification de l'aménagement forestier. L'analyse comparative a révélé que plusieurs caractéristiques des peuplements forestiers ont été modifiées de façon significative entre 1993 et 2003, probablement par suite du changement de tenure, tandis que la plupart des caractéristiques d'aménagement forestier ne l'ont pas été. Nos résultats suggèrent qu'un changement drastique de la législation forestière n'entraîne pas nécessairement un changement radical des caractéristiques descriptives des ressources forestières dans le cas de cette juridiction, mais plutôt dans la structure de la forêt.

Mots clés : transition économique, Europe de l'Est, foresterie, politiques, statistiques non paramétriques

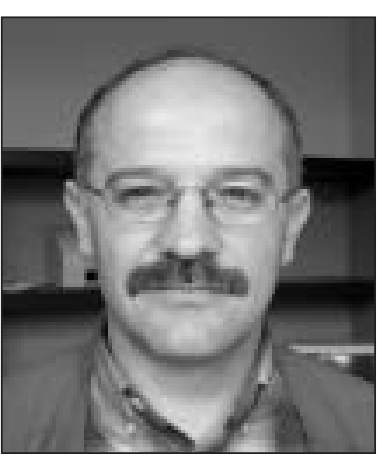

Bogdan M. Strimbu

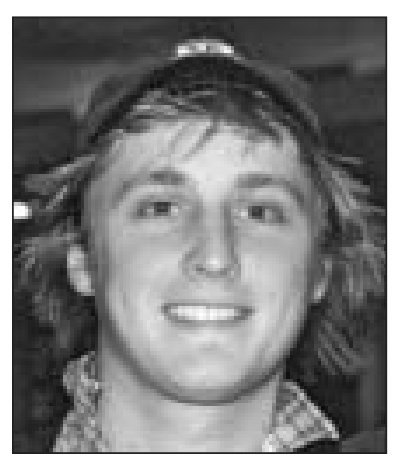

Gordon M. Hickey

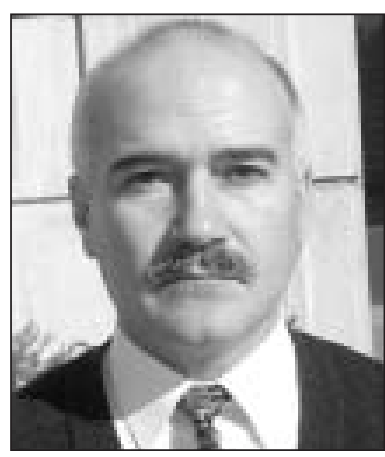

Vladimir G. Strimbu

terms of forest management, objectives related to forest protection and forest industry renewal have led to changes in forest policy. This has resulted in new forest laws that have led to institutional reform, particularly in terms of forest ownership (Csóka 2005).

Southeast European economies in transition

The countries of southeastern Europe share a number of socio-cultural similarities.

\section{Introduction}

Throughout post-communist Europe, many economies have performed less well than expected resulting in a range of socio-political pressures being placed on governments. According Sotiropoulos et al. (2003) this situation is particularly evident in the countries of southeastern Europe. In

\footnotetext{
${ }^{1}$ Department of Forest Resources Management, Faculty of Forestry, University of British Columbia, 2045-2424 Main Mall, Vancouver, BC.

${ }^{2}$ Corresponding author. E-mail: strimbu@interchange.ubc.ca

${ }^{3}$ Ministry of Agriculture, Forests and Rural Development, Bucharest, Romania.
} Papadimitriou and Phinnemore (2004) noted that each country has incorporated important elements of post-communism in their domestic politics, while residual strains of transition exist in the social, economic and political arenas. From 1989 onwards, the countries of Southeastern Europe experienced a post-communist transition towards the market economy. According to Sotiropoulos et al. (2003), in each case governments faced the dilemma of trying to balance conflicting demands for greater economic efficiency, with demands for enhanced social protection. More recently, one of the major challenges facing the countries of Southeastern Europe has been obtaining membership of the European Union (EU) (Papadimitriou and Phinnemore 2004). 
Table 1. Forest ownership change in selected Eastern European countries (1997-2002)

\begin{tabular}{|c|c|c|c|c|c|c|c|}
\hline \multirow[t]{2}{*}{ Country } & \multicolumn{2}{|c|}{$\begin{array}{c}\text { Forested } \\
\text { area }\end{array}$} & \multicolumn{2}{|c|}{ State-owned } & \multicolumn{2}{|c|}{$\begin{array}{c}\text { Non- } \\
\text { state-owned }\end{array}$} & \multirow{2}{*}{$\begin{array}{c}\text { Change } \\
\%\end{array}$} \\
\hline & $(\mathrm{m}$ & ion ha) & 1997 & 2002 & 1997 & 2002 & \\
\hline Czech Repu & blic & 2.6 & $63^{4}$ & $61^{3}$ & $37^{4}$ & $39^{3}$ & 2 \\
\hline Poland & & 8.6 & $84^{1}$ & $83^{5}$ & $16^{1}$ & $17^{5}$ & 1 \\
\hline Romania & & 6.4 & $95^{1}$ & $70^{3}$ & $5^{1}$ & $30^{3}$ & 25 \\
\hline Slovakia & & 2.0 & $55^{1}$ & $55^{4}$ & $45^{1}$ & $45^{4}$ & 0 \\
\hline Hungary & & 1.6 & $57^{2}$ & $60^{3}$ & $43^{2}$ & $40^{3}$ & -3 \\
\hline Bulgaria & & 3.3 & $>75^{2}$ & $82^{3}$ & $<25^{2}$ & $18^{3}$ & - \\
\hline Slovenia & & 1.1 & $33^{1}$ & $30^{3}$ & $67^{1}$ & $70^{3}$ & 3 \\
\hline
\end{tabular}

${ }^{1}$ Issues and Opportunities in the Evolution of Private Forestry and Forestry

Extension in Several Countries with Economies in Transition in Central and Eastern Europe, FAO, Rome 1997

${ }^{2}$ Proceedings of the FAO/Austria expert meeting on environmentally sound forest operations for countries in transition to market economies, FAO, Ort/Gmunden, Austria, 1999

${ }^{3}$ World Summit on Sustainable Development, United Nation, Johannesburg 2002 ${ }^{4} \mathrm{MCPFE}$ Liasion Unit Vienna and UNECE/FAO. Status of Europe's Forests 2003. Vienna, 2003

${ }^{5}$ United Nation Forum of Forests. National Report to the Fifth Session of the United Nations Forum on Forests: Poland, New York, 2004

In terms of forest management in the region, the main changes have involved property transfer from state to nonstate agencies (see Table 1). Csóka (2005) noted that, due to uncertainties about the long-term nature of these changes, many of the new private forest owners wanted to make money from their properties as soon as possible by harvesting and selling wood, without necessarily considering sustainability.

\section{Romania's market transition}

Romania is situated in the lower Danube basin and borders the Black Sea (Kirby and Heap 1984). According to Rizov (2004), Romania faced particularly difficult initial conditions for transition towards the market economy ${ }^{4}$. The process of democratizing Romania has also been very difficult (Badescu et al. 2004), where a loss of social identity and entrepreneurship were combined with high levels of endemic corruption and politicization (Al Khatib et al. 2004, Papadimitriou and Phinnemore 2004, Stan and Turesu 2004). As a result, Romania's economy declined throughout the 1990s, with inflation reaching 295 percent in 1993, and unemployment increasing to 11.8 percent in 1999 (see Table 2).

Since the onset of transition, inefficiency, corruption and lack of expertise have been very damaging for Romania's civil services (Papadimitriou and Phinnemore 2004). Nevertheless, Murrell (2003) noted that several cross-country evaluations have found Romanian courts to be typical or better than average among transition countries in upholding contract and property rights [e.g., Hellman et al. (2000), Johnson et al. (2002), Djankov et al. (2003)].

\footnotetext{
${ }^{4}$ Under the leadership of Ceausescu, Romania experienced a drive towards industrialization that has resulted in an inefficient industrial structure (Rizov 2004).
}

Table 2. Macroeconomic indicators for Romania (1990-2000)

\begin{tabular}{|c|c|c|c|c|c|c|}
\hline \multirow[b]{2}{*}{ Year } & \multicolumn{6}{|c|}{ General macroeconomic indicators } \\
\hline & $\begin{array}{l}\text { GDP } \\
\text { growth } \\
(\%)\end{array}$ & $\begin{array}{c}\text { Unem- } \\
\text { ployment } \\
\text { (\% of } \\
\text { labour } \\
\text { force) }\end{array}$ & $\begin{array}{c}\text { Inflation } \\
\text { (\% p.a.) }\end{array}$ & $\begin{array}{l}\text { Govern- } \\
\text { ment } \\
\text { budget } \\
\text { balance } \\
\text { (\%GDP) }\end{array}$ & $\begin{array}{c}\text { External } \\
\text { debt } \\
(\% \text { GDP })\end{array}$ & $\begin{array}{c}\text { Inter- } \\
\text { bank } \\
\text { interest } \\
\text { rate } \\
\text { (\% p.a.) }\end{array}$ \\
\hline 1990 & -5.6 & - & 37.7 & 1.0 & 3.0 & 3.8 \\
\hline 1991 & -12.9 & - & 222.8 & 0.6 & 7.4 & 19.5 \\
\hline 1992 & -8.8 & - & 199.2 & -4.6 & 16.5 & 43.6 \\
\hline 1993 & 1.5 & 10.4 & 295.5 & -0.4 & 16.1 & 61.4 \\
\hline 1994 & 3.9 & 10.9 & 61.7 & -2.2 & 18.3 & 64.3 \\
\hline 1995 & 7.1 & 9.5 & 27.8 & -2.5 & 19.1 & 45.2 \\
\hline 1996 & 3.9 & 6.6 & 56.9 & -3.9 & 24.3 & 55.3 \\
\hline 1997 & -6.1 & 8.9 & 151.4 & -4.6 & 27.1 & 90.3 \\
\hline 1998 & -5.4 & 10.3 & 40.6 & -5.0 & 26.1 & 136.4 \\
\hline 1999 & -3.2 & 11.8 & 54.8 & -3.5 & 25.8 & 58.9 \\
\hline 2000 & 1.6 & 10.5 & 40.7 & -3.7 & 27.8 & - \\
\hline
\end{tabular}

Source: Rizov (2004) [based on data from the European Bank for Reconstruction and Development (EBRD), the International Monetary Fund (IMF), and the Öesterreichische Nationalbank (ÖNB)]

\section{Forestry in Romania}

Based on endemic species biodiversity richness, Romania ranks sixth in Europe (Oszlanyi et al. 2004). Romania's forests are dominated by broadleaved tree species that cover $70 \%$ of the forest land base (see Table 3). Romania has more than six million hectares of forest, with the main species being European beech (Fagus sylvatica), Norway spruce (Picea abies) and European (Silver) fir (Abies alba). Under communism, Romania invested heavily in forest management, producing some of Europe's best silviculture and technical specialists (World Bank 2002).

Forest management in Romania has been shaped by three forestry codes (1881, 1962 and 1996). After the fall of communism in 1989, two laws have determined the status of land and ownership in Romania: 1) the Land Use Law (Bill 18/1991) and 2) the Property Restitution Law (Bill 1/2000). These Acts have led the shift from an entirely state-owned forest resource to a mixture of private and state-owned forest land. According to the World Bank (2002), the process of transition has led to reduced production and employment in Romania's forest sector resulting in undervalued and underutilized forests resources. Further, Oszlanyi et al. (2004) noted that while Romania was one of the first European countries to take strong actions designed to protect its natural heritage, the recent nature protection actions have been inadequate (see also Ellison 2004).

Our research investigates the extent to which Romania's forest property transfer has induced forest management transformation, and/or impacted the forest structure.

\section{Methods}

\section{Study area}

Based on their high rate of forest privatization between 1997 and 2002, we have selected Romania as an appropriate case study from Southeastern Europe (see Table 1). To better consider the range of forest ecosystems present in Romania, we 
Table 3. Summary of Romania's forested area for year 2004 (million ha)

\begin{tabular}{|c|c|c|c|c|c|c|c|}
\hline \multicolumn{2}{|c|}{ Phyto-climatic Zone } & \multicolumn{2}{|l|}{ Ownership } & \multicolumn{2}{|l|}{ Forest type } & \multicolumn{2}{|l|}{ Zonation } \\
\hline Mountains (FM) & 4.2 & State & 4.4 & Coniferous & 1.6 & Forest for water protection & 0.9 \\
\hline Hills (FD) & 1.5 & Non-state & 1.9 & Broadleaved & 4.7 & Forest for soil protection & 1.2 \\
\hline \multirow[t]{2}{*}{ Plains (CF) } & 0.6 & & & & & Recreation, science and climate & 0.8 \\
\hline & & & & & & Production forests & 3.4 \\
\hline
\end{tabular}

Source: Romanian National Forest Administration (2005).

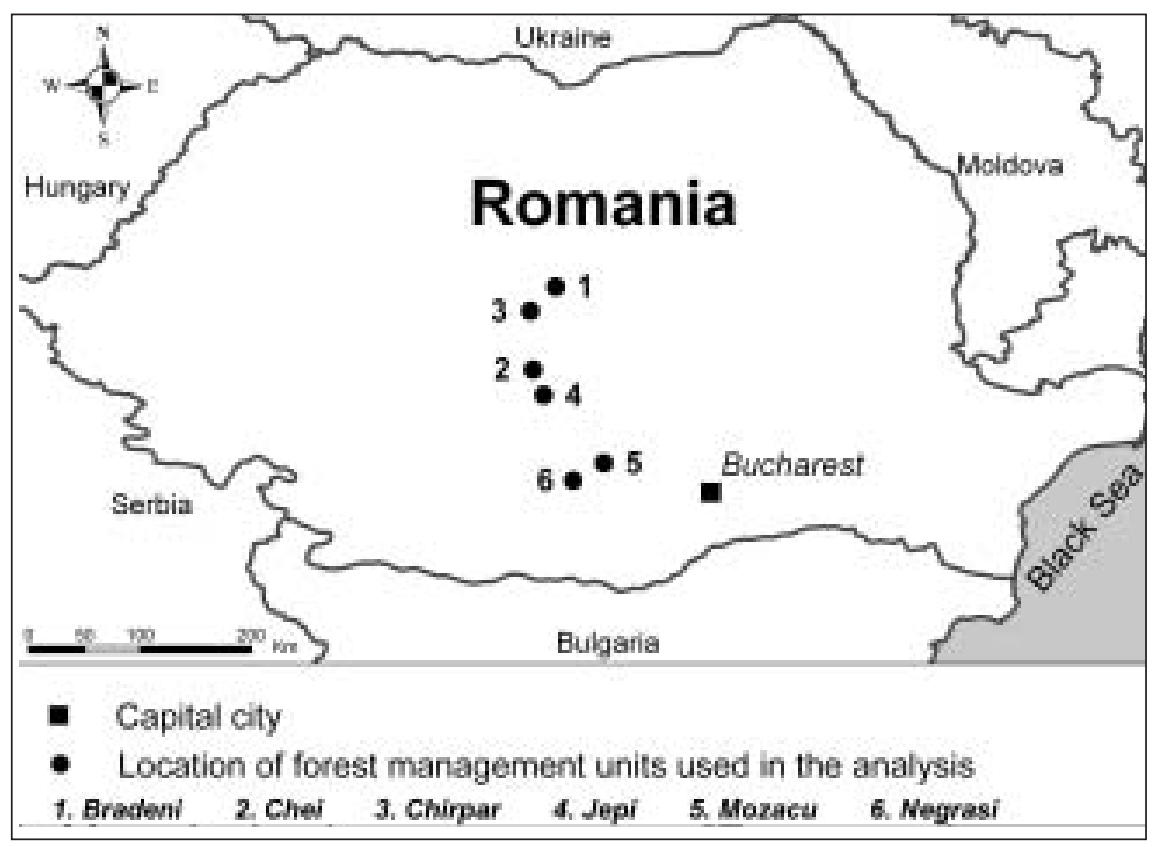

Fig. 1. Location of the study areas. ern forest ownership eras. The data representing the state forest ownership era were taken from 1993, while data from 2003 were used to consider the mixed private/state ownership era. For each time period, seven attributes describing the forest stand (i.e., altitude, diameter, height, canopy closure, productivity class, leading species, surface area) (see Davis et al. 2001) and four attributes characterizing the legislation (i.e., zonation, harvesting age $\mathrm{e}^{7}$, ownership, treatment) were recorded within each management unit. Overall, data from 604 managed forest stands (i.e., homogeneous forest ecosystem units between 0.5 and $60 \mathrm{ha})$, were recorded using a repeated measurements design (Everitt 1994). All of the sampled stands were actively managed for production or protection in both 1993 and 2003.

\section{Data analysis}

We performed an aspatial investigation of the forest dynamics in the study separated our data based on Romania's national "phytoclimatic zones," resulting in a stratified random sample. We then used the proportional allocation method to determine the sample size of each stratum (Cochran 1977). This led to a random selection of $\operatorname{six}^{5}$ forest management units (i.e., the fundamental unit for which a Romanian forest management plan is elaborated). Using forest resources inventory data obtained from the Romanian National Forest Administration (NFA) (2003), two management units were subsequently allocated to each phyto-climatic zone. This resulted in a stratified random sample with equal allocation. ${ }^{6}$ Fig. 1 shows the geographic location of the management units.

\section{Data description}

To analyse the forest dynamics under rapid legislation change, two time periods were selected to represent Romania's mod-

\footnotetext{
$\overline{{ }^{5} \text { Our calculations were based on a population of } 2500 \text { managed }}$ forest units. The desired precision (in \% of the mean) was $20 \%$, $=0.05$. The coefficient of variation was determined using data from Grodzinska et al. (2004).

${ }^{6}$ We transformed the management unit allocation from "proportional" to "equal" because proportional allocation resulted in only one management unit in the plain and hills phyto-climatic zones. This transformation did not bias the results because both methods provide unbiased estimates of the elements that characterize central tendency (Cochran 1977).
} areas by pooling the data from each management unit. Using this pooled data, we assessed changes in forest condition in response to legislative changes related to ownership by testing for differences between the attributes in the two time periods. To ensure the effectiveness of our statistical analysis, the independence of the attributes describing either the forest or the legislation were assessed using Pearson correlation coefficients.

Traditionally, $t$ and $F$ tests are used to evaluate the difference between estimators of the central tendency and the dispersion (Levin 1981). However, these tests will only supply correct and unbiased results when the errors are independent (Harnett and Murphy 1986), the data are normally distributed (Fisher 1935) and the variances are homogeneous (Neter et al. 1996).

The compound symmetry condition, required by the repeated measures design, was met because only two time periods were considered (Geisser 1963, Shoukri and Pause 1999). Nevertheless, an adjusted $F$-test was used for the analysis (Box 1954a, b; Crowder and Hand 1990; Dawson and Lagakos

\footnotetext{
${ }^{7}$ In Romania, the harvesting age is calculated based on forest zonation, species and productivity class (Ministerul silviculturii 1986). It is, therefore, very susceptible to changes in administration because zonation incorporates a political view of the forest.
} 
Table 4. Summary statistics for the sampled management units

\begin{tabular}{|c|c|c|c|c|c|c|c|c|c|c|c|c|}
\hline $\begin{array}{l}\text { Manage- } \\
\text { ment } \\
\text { unit }\end{array}$ & Year & $\begin{array}{l}\text { Phyto- } \\
\text { climatic } \\
\text { zone }\end{array}$ & $\begin{array}{l}\text { Altitude } \\
{[\mathrm{m}]}\end{array}$ & $\begin{array}{c}\text { Surface } \\
\text { [ha] }\end{array}$ & $\begin{array}{c}\text { Managed } \\
\text { Stands } \\
{[\#]}\end{array}$ & $\begin{array}{c}\text { Age } \\
\text { [years] }\end{array}$ & $\begin{array}{c}\text { Canopy } \\
\text { closure } \\
{[\%]}\end{array}$ & $\begin{array}{l}\text { Diameter } \\
{[\mathrm{cm}]}\end{array}$ & $\begin{array}{l}\text { Height } \\
{[\mathrm{m}]}\end{array}$ & $\begin{array}{c}\text { Productivity } \\
\text { class } \\
\text { [index] }\end{array}$ & $\begin{array}{c}\text { Harvesting } \\
\text { age } \\
\text { [years] }\end{array}$ & $\begin{array}{c}\text { State- } \\
\text { owned } \\
{[\%]}\end{array}$ \\
\hline \multirow[t]{2}{*}{ Bradeni } & 1993 & FD & $490-670$ & .7 & 37 & $56[32.1]$ & $0.79\left[0.15^{\star}\right]$ & 21.5 [12.5] & $16.9[8.0]$ & $2.6[0.7]$ & 85 [39.7] & 100 \\
\hline & 2003 & FD & $480-710$ & 595.4 & 37 & 58 [28.1] & $0.84\left[0.55^{\star}\right]$ & $23.3[11.8]$ & $17.5[7.7]$ & $2.7[0.5]$ & 82 [37.2] & 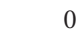 \\
\hline \multirow[t]{2}{*}{ Chei } & 1993 & FM & $660-1500$ & 1918.6 & 90 & $101[67.6]$ & $0.75[0.13]$ & $39.8[24.1]$ & $21.5[11.0]$ & $2.8[0.8]$ & 105 [26.7] & 100 \\
\hline & 2003 & FM & $660-15$ & 1 & 92 & $98[65$ & $0.76[0.16]$ & 37.7 [21.3] & $22.3[9.5]$ & $2.8[0.8]$ & $102[30.6]$ & 99 \\
\hline \multirow[t]{2}{*}{ Chirpar } & 1993 & $\mathrm{FD}$ & $430-680$ & 1300.9 & & $60 *[31.9]$ & $0.81[0.1]$ & $24.3[14.1]$ & $17.2\left[6.3^{\star}\right]$ & $3.1[0.4]$ & 82 [35.9] & 100 \\
\hline & 2003 & FD & 400-680 & .7 & & $69^{*}$ & $.1]$ & 28.0 & $19.2\left[4.9^{*}\right]$ & 3.1 & $79[36.3]$ & 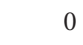 \\
\hline \multirow[t]{2}{*}{ Jepi } & 1993 & FM & $900-2000$ & 3731.8 & 170 & $98^{\star}\left[56.7^{\star}\right]$ & $0.71\left[0.14^{*}\right]$ & 39.9 [20.8] & $24.6[11.0]$ & $2.6\left[0.7^{\star}\right]$ & $102^{\star}\left[28.4^{\star}\right]$ & 100 \\
\hline & 2003 & FM & $900-2000$ & 3307.8 & 171 & $87^{\star}\left[66.2^{\star}\right]$ & $0.66\left[0.25^{\star}\right]$ & 35.3 [24.2] & $21.0[12.4]$ & $2.4\left[1.0^{*}\right]$ & $90^{\star}\left[42.1^{\star}\right]$ & 96 \\
\hline \multirow[t]{2}{*}{ моzacu } & 1993 & $\mathrm{CF}$ & 103-204 & 1726.5 & 145 & $22.4\left[11.6^{\star}\right]$ & $0.88^{\star}\left[0.05^{\star}\right]$ & $11.6\left[3.1^{\star}\right]$ & $10.4\left[2.8^{\star}\right]$ & $3.0\left[0.1^{\star}\right]$ & $75^{\star}\left[23.2^{\star}\right]$ & 100 \\
\hline & 2003 & $\mathrm{CF}$ & 103-204 & 1672.7 & 146 & $27.3\left[16.5^{\star}\right]$ & $0.75^{\star}\left[0.27^{\star}\right]$ & $13.2\left[6.3^{\star}\right]$ & $10.5\left[5.1^{\star}\right]$ & $2.7\left[1.0^{*}\right]$ & $\left.65^{\star} 31.9^{*}\right]$ & 85 \\
\hline \multirow[t]{2}{*}{ Negrasi } & 1993 & $\mathrm{CF}$ & $185-210$ & 1091.4 & 90 & $18^{*}\left[8.3^{\star}\right]$ & $0.90^{*}\left[0.43^{\star}\right]$ & $10.4\left[3.1^{*}\right]$ & $9.3\left[3.1^{\star}\right]$ & $3.0\left[0.3^{\star}\right]$ & $69^{*}\left[22.8^{\star}\right]$ & 100 \\
\hline & 2003 & $\mathrm{CF}$ & $185-210$ & 1058.2 & 90 & $10^{*}\left[14.8^{\star}\right]$ & $0.34^{\star}\left[0.42^{\star}\right]$ & $5.1\left[7.8^{\star}\right]$ & $3.8\left[5.4^{\star}\right]$ & $1.2\left[1.5^{\star}\right]$ & $28^{*}\left[36.9^{*}\right]$ & 36 \\
\hline \multirow[t]{2}{*}{ Total } & 1993 & - & $103-2000$ & 10346.9 & 604 & & & & & & 88 [31.3] & 100 \\
\hline & 2003 & - & $103-2000$ & 9747.9 & 608 & $59[56.5]$ & $0.65[0.33]$ & $22.9[20.6]$ & $14.8[11.1]$ & $2.3[1.2]$ & 75 [42.9] & 70 \\
\hline
\end{tabular}

FM-Mountain phyto-climatic zone, FD- hills phyto-climatic zone, CF-plain phyto-climatic zone

For canopy closure, diameter, height and productivity class the first number is the mean and the second is the [standard deviation].

* significant difference between 1993 and 2003 for the same management unit at $\alpha=0.05$

1993). Furthermore, we have followed the recommendations of Looney and Stanley (1989) when conducting hypothesis testing in a repeated measures design by using a hierarchical hypotheses testing framework.

Glass et al. (1972) used a series of examples to show that $t$ and $F$ tests are robust to the normality assumption. However, more recent studies have demonstrated that these tests only become robust to the normality assumption when specific procedures or adjustments are used (see Rao et al. 1993, Keselman et al. 1997, Cain et al. 2000, Shoemaker 2003, Islam and Tiku 2004). Therefore, when we discovered that certain attribute data were not normally distributed, we performed comparisons using two non-parametric tests: Wilcoxon (Wilcoxon 1945) and Friedman (Friedman 1937). We also used a parametric test, Cochran-Mantel-Haenszel (Zhang and Boos 1997), considered robust to approximations (Fidalgo et al. 2000). The nonparametric tests used in analysis were adjusted to the repeated measures design (Bradley 1968, Hollander and Wolfe 1973, Lehmann and D'Abrera 1975). To check the normality of our data we used the Shapiro-Wilk (Shapiro and Wilk 1965), KolmogorovSmirnov, Cramer-von Mises and Anderson-Darling (Stephens 1974) tests.

The Wilcoxon test was used to assess changes in forest structure (age classes, canopy closure, diameter, height and harvesting age) between the two periods. We used the Friedman test ${ }^{8}$ to compare the zonation and the forest treatments between 1993 and 2003. It was also used to assess the structural differences in age class for each phyto-climatic zone, productivity class, species composition and the influence of the elevation on species composition between the two periods. The Cochran-Mantel-Haenszel (CMH) test was used to assess the influence of the forest ownership on the zonation

\footnotetext{
${ }^{8}$ The Friedman test is the non-parametric version of the two-way ANOVA.
}

and the forest treatments. The same test was employed to assess changes in the age class structure with respect to elevation, and species composition with respect to phyto-climatic zones. All statistical analyses were performed using SAS (v.9.1.3).

\section{Assumptions and limitations}

We have assumed that for those attributes where there was not enough evidence to reject the null hypothesis (i.e., there is no difference between the forested landscape in the two periods), it could be inferred that there was no evidence that changes in forest ownership laws caused significant changes to the forested landscape.

When interpreting the results, it was important to note that the non-parametric tests used to assess changes in the forest structure attributes are less sensitive to outliers than $t$ or $F$ tests (Harnett and Murphy 1986). Furthermore, the asymptotic relative efficiency of nonparametric tests is relatively low (i.e., 0.955) compared with the parametric tests only for normally distributed data, but can be infinity when the normality assumption is violated (Hodges, Jr. and Lehmann 1956, Conover 1998).

\section{Results}

\section{Summary statistics}

Our analysis of the summary statistics for each forest management unit (Table 4) showed that no significant difference ( $\alpha=0.05)$ existed between the two time periods for average canopy closure, diameter, height and productivity class in the "mountain" (FM) and "hills" (FD) phyto-climatic zones. The forest located in the "plains" (CF) phyto-climatic zone were more diverse, with all attributes revealing a significant decrease between the time periods, except for diameter and height in the Mozacu forest management unit. A general decline in the forest harvesting age was found to exist for all of the forest management units, with a significant decrease observed in the "plains" (CF) zone. The data taken from the 
Table 5. Correlation coefficients between the attributes used in analysis

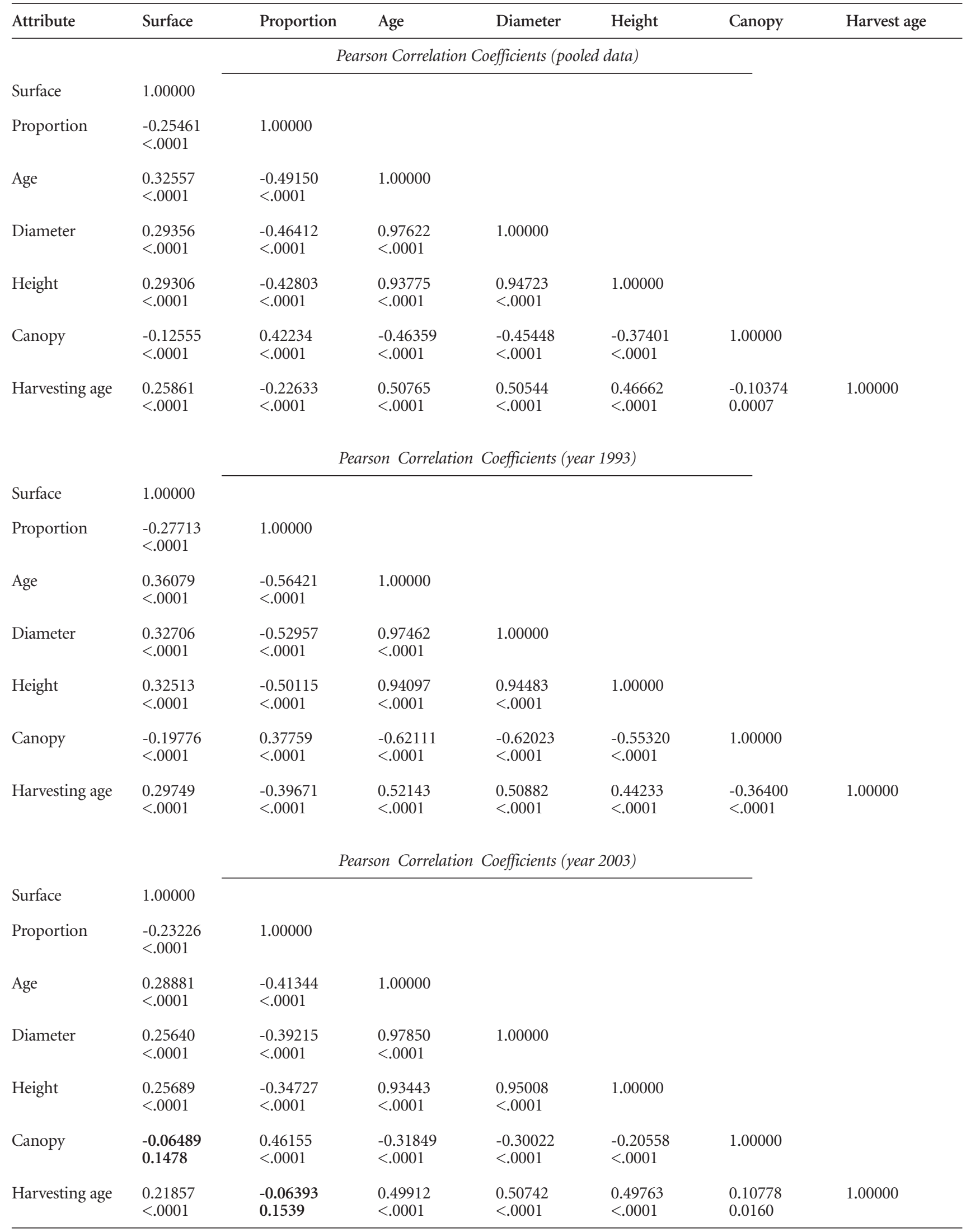

Bold indicates that the correlation coefficients are not significantly different than zero $(\alpha=0.05)$ 

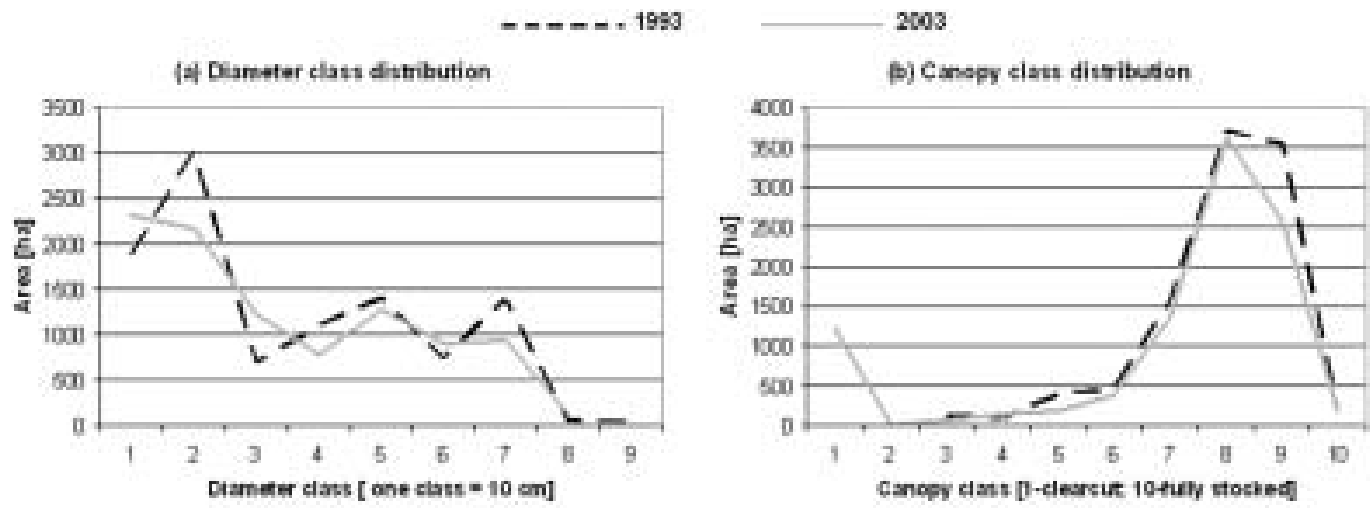

(c) Stand height class distributven

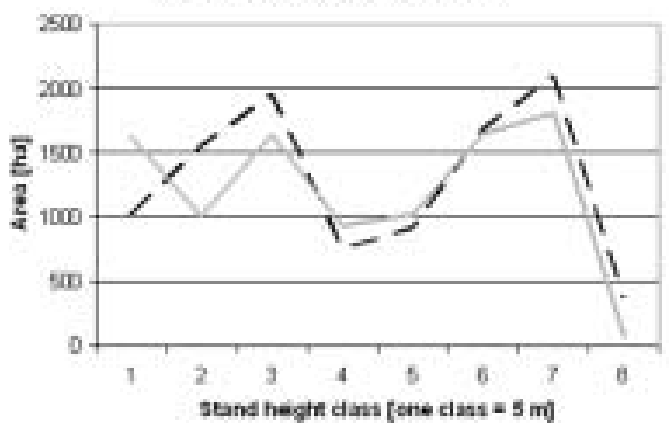

(d) Age class derribution

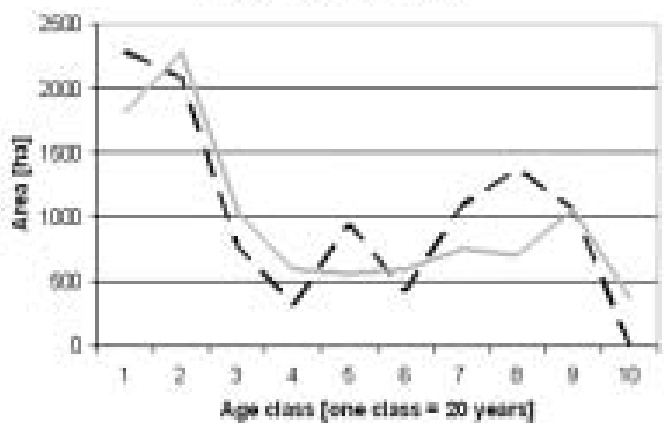

Fig. 2. Selected forest attribute data (pooled) 1993 and 2003.

CF zone indicated a number of differences when compared to the FD and FD phyto-climatic zones, particularly in terms of forest ownership.

The correlation matrix (Table 5) shows the attributes interdependence. For both the "pooled" and "1993" data we found significant correlations between the surface area, species proportion, age, diameter, height, canopy closure and harvesting age. The same conclusion holds for " 2003 ” except no significant differences were found between canopy closure and stand surface or harvesting age and species proportions.

\section{Comparative analysis}

The non-structural comparison of attributes identified the presence or absence of significant changes between 1993 and 2003. No significant differences were found in the forest diameter classes between the two periods (Fig. 2a). Significant differences were found to exist in canopy closure (Fig. 2b), forest height classes (Fig. 2c) and age classes (Fig. 2d), between 1993 and 2003. For the 2003 data, the presence of stands older than 160 years revealed an increase in the forest age range. This range increase was also observed for the diameter classes. The height and canopy closure data showed no change in their range between the two time periods.

Stand productivity in the two time periods (Fig. 3) revealed a general migration from "superior" toward "inferior" productivity, regardless of the phyto-climatic zone.
Our analysis revealed that the data for each attribute listed in Table 6 were not normally distributed $(\alpha=0.05)^{9}$. Therefore, non-parametric tests were used to compare changes in the structural attributes between the two time periods. The results (Table 6) show that the change in forest ownership did not affect the species composition and age distribution in the study areas. However, the remaining forest attributes (i.e., canopy closure, diameter, height and productivity class) were significantly affected by the legislative changes. Further analysis of the data related to species composition and age class structure revealed that the forest's phyto-climatic zone had no significant influence on the changes in species composition between the two time periods $(p=0.279)$ while age class structure was significantly impacted $(\mathrm{p}<0.001)$. Elevation was found to have a significant impact on the species composition between the two periods $(\mathrm{p}<0.001)$ and no influence on the age class structure $(\mathrm{p}=0.17)$.

While most of the forest stand-related attributes were affected between 1993 and 2003, a different perspective is offered by the comparison of administrative attributes (Table 6). Of the attributes describing forest legislation, only the har-

${ }^{9}$ The non-normality of the data warned us that the results of the $t$ and $F$ tests could not be relied upon. Nevertheless, these tests do provide and indication about the presence or absence of relationships in the data. 


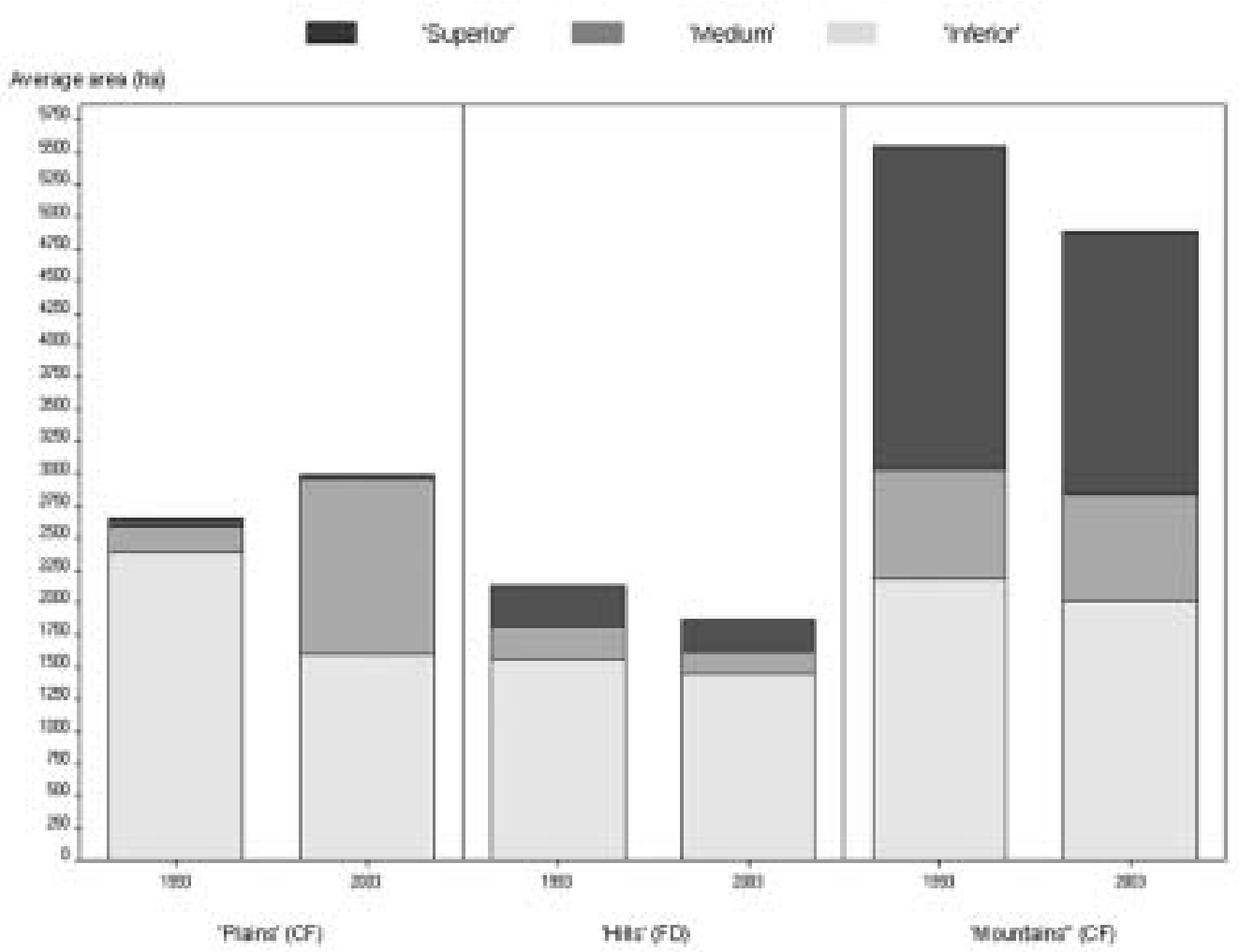

Phyto-elimatic Zones (Romania)

Fig. 3. Productivity class distribution (1993 and 2003).

Table 6. Change in selected attributes between 1993 and $2003(\alpha=0.05)$

Null hypothesis

Wilcoxon

Friedman

Cochran-

Mantel-Haenszel

The age class structure did not change

The phyto-climatic zones did not influence the age class structure for the two periods

The elevation did not influence the age class structure for the two periods

The canopy closure structure did not change

The diameter class structure did not change

The height class structure did not change

The productivity class structure did not change

The species composition structure did not change

The phyto-climatic zones did not influence the species composition for the two periods

The elevation did not influence the species composition for the two periods

The harvesting age did not change

The zonation structure did not change

The owners did not change the zonation

The treatments did not change

The treatments by owner did not change
Accept $(\mathrm{p}=0.54)$

Reject $(\mathrm{p}<0.001)$

Reject $(\mathrm{p}<0.001)$

Reject $(\mathrm{p}<0.001)$

$$
-
$$$$
-
$$$$
-
$$

$-$

Reject $(\mathrm{p}=0.01)$

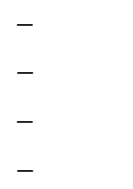

Reject $(\mathrm{p}<0.001)$

\begin{tabular}{|c|c|}
\hline- & Accept $(\mathrm{p}=0.17)$ \\
\hline- & - \\
\hline- & - \\
\hline- & - \\
\hline Reject $(\mathrm{p}<0.001)$ & - \\
\hline Accept $(\mathrm{p}=0.08)$ & - \\
\hline- & Accept $(\mathrm{p}=0.279)$ \\
\hline Reject $(\mathrm{p}<0.001)$ & - \\
\hline- & - \\
\hline Accept $(\mathrm{p}=0.564)$ & - \\
\hline- & Reject $(\mathrm{p}<0.001)$ \\
\hline Accept $(\mathrm{p}=0.479)$ & - \\
\hline - & Reject $(\mathrm{p}<0.001)$ \\
\hline
\end{tabular}


vesting age was found to have decreased significantly between 1993 and 2003. The forest zonation and treatments were not significantly affected by the property transfer. However, the ownership status was found to have a significant influence on the zonation and treatment selection. These results enhance the information provided by both the $t$ and $F$ tests used in the summary statistics (Table 4) and the correlation matrix (Table 5).

\section{Discussion}

Romania's forest legislation has changed four times in the last decade resulting in a significant change in the forest ownership structure. While these legislation changes were found to have less impact on the descriptive forest attributes, significant changes were found in the forest structure. These differences were often hidden behind simple statistical comparisons. This discrepancy, which reflected the difference between broad and detailed comparative analysis methods, revealed that the rapid change in forest ownership legislation may have induced significant structural changes to the forest.

The summary statistics (see Table 4) indicated a pattern in landscape-level changes between 1993 and 2003. In 1993 all of the attributes describing forest condition exhibited a small degree of variability, while in 2003 the attributes describing the forests in the "plains" phyto-climatic zone revealed an increase in variability. This is also the zone where the greatest mixture of forest ownership existed. While this result can be seen to indicate problems in the transfer of forest property rights, it is important to note that forest privatization, in its classic sense, has been very limited in Romania, where the change in forest ownership (see Table 1) is predominantly the result of the restitution process (World Bank 2002, Csóka 2005). This has resulted in a large number of small, nonindustrial private forest owners.

The Pearson's correlation coefficient matrix for the pooled data (see Table 5) has the same structure in the two time periods suggesting that dependencies exist among the major attributes used in forest planning. These correlation coefficients also confirm the biometric relationship expected between the forest stand attributes (Avery and Burkhart 2001) and indicates a relationship between the forest stand and the landscape. However, the stand's surface area was found to have a negative relationship with main species proportions and canopy closure. This decrease in tree species variability in the larger stands is explained by the Romanian forest management practices (Ministerul silviculturii 1986), where older forest stands are usually more homogeneous than younger stands. The negative relationship between species proportion and stand age indicates that the species in the younger forest stands were more variable and explains the negative correlation observed between species proportion and both diameter and height attribute data.

In our study areas, all of the forest stand attributes, except age and species composition (i.e., canopy closure, diameter, height, and productivity class) were found to have suffered significant structural changes between 1993 and 2003. These changes were not for the better, with all attributes decreasing by at least $10 \%$ while variability increased. This trend was observed for both private and state-owned forests and may indicate difficulties in the forest industry's adaptation to the free market. In Romania, the Property Restitution Law allows a maximum of 0.5 hectares of forest to be returned to each pri- vate forest owner, while the forestry regulations, based on the Forest Code (Law No. 26 of 1996), allows the clearcut harvesting of forest areas up to 3 hectares. In 2002, the World Bank noted: "[p]revious experience in Romania and elsewhere has shown that if the restitution of forest lands takes place without adequate legal and institutional mechanisms, the almost immediate loss of forest cover is likely to result, leading to irreversible environmental degradation and significant economic losses for the country." While our results indicate no change in the forest cover, they do suggest that legal and institutional reform may have resulted in forest degradation.

Our research also suggests that the technical aspects of the forest regulations (i.e., zonation and treatments) did not change significantly between the two time periods (Moise and Strimbu 2000). These results confirm the stability of forest regulation in our study areas (see Table 6). However, there were significant differences found for forest zonation and forest treatments between 1993 and 2003 that might be attributed to changes in ownership. Canarache (2004) noted that the recent change in Romania's land ownership structure has resulted in new management styles. Our results support this observation and may indicate new forest management objectives designed to ensure profit. In Romania, this objective is often achieved by reducing the harvesting age (see Moise and Strimbu 2000).

According to the World Bank (2002) and Csóka (2005), the volume of wood coming from sustainably managed forests in Romania decreased considerably during the economic transition, resulting in harvesting levels that were well below the mean annual increment of the forest. While a decrease in harvesting levels between 1993 and 2003 would have resulted in a general increase in the magnitude of the major forest biometric attributes (i.e., canopy closure, diameter, height) our data indicated a general decrease over the period. Therefore, our results do not support this assertion.

\section{Conclusion}

Using data from Romania, a range of statistical tests were used to evaluate the effects of post-communist economic transition on forest resources. Our results suggest that a dramatic change in forest ownership legislation does not necessarily result in a dramatic change in the descriptive characteristics of forest resources in that jurisdiction but, rather, in the structure of the forest. While we recognize that the evolution of forest management practices in post-communist southeastern Europe is extremely complex, this research supports further investigation into the factors affecting forests in the region. This will help policy makers as they balance political pressures to return forest lands to their former owners with the need to develop a monitoring framework capable of ensuring sustainable forest management.

\section{Acknowledgements}

We would like to acknowledge the support of Professor John Innes, University of British Columbia, Canada.

\section{References}

Al-Khatib, J.A., C.J. Robertson and D.N. Lascu. 2004. Post-communist consumer ethics: The case of Romania. Journal of Business Ethics. 54: 81-95.

Avery, T.E. and H. Burkhart. 2001. Forest Measurements. McGrawHill Ryerson, New York.

Badescu, G., P. Sum, and E.M. Uslaner. 2004. Civil society develop- 
ment and democratic values in Romania and Moldova. East European Politics and Societies 18: 316-341.

Box, G.E.P. 1954a. Some Theorems on Quadratic Forms Applied in the Study of Analysis of Variance Problems, I. Effect of Inequality of Variance in the One-Way Classification. The Annals of Mathematical Statistics 25: 290-302.

Box, G.E.P. 1954b. Some Theorems on Quadratic Forms Applied in the Study of Analysis of Variance Problems, II. Effects of Inequality of Variance and of Correlation Between Errors in the Two-Way Classification. The Annals of Mathematical Statistics 25: 484-498.

Bradley, J.V. 1968. Distribution free statistical tests. Prentice-Hall, Inc., Englewood Cliffs.

Cain, M., D. Law and D.A. Peel. 2000. Testing for statistical and market efficiency when forecast errors are non-normal: the NFL betting market revisited. Journal of Forecasting 19: 575-586.

Canarache, A. 2004. Romania. Journal of Soil and Water Conservation 59: 40A-41A.

Cochran, W.G. 1977. Sampling techniques. John Wiley and Sons, Singapore.

Conover, W.J. 1998. Practical Nonparametric Statistics. John Wiley and Sons, New York.

Crowder, M.J. and D.J. Hand. 1990. Analysis of repeated measures. Chapman and Hall, London.

Csóka, P. 2005. Capital Management - the Forests in Countries in Transition - Welfare Impacts. In J.L. Innes, G.M. Hickey and H.F. Hoen (eds.). Forestry and Environmental Change: Socio-economic and Political Dimensions. CABI Publishing, Oxford.

Davis, L. S., K.N. Johnson, T.E. Howard and P. Bettinger. 2001. Forest management. McGraw-Hill, New York.

Dawson, J.D. and S.W. Lagakos. 1993. Size and Power of TwoSample Tests of Repeated Measures Data. Biometrics 49: 1022-1032. Djankov, S., R. La Porta, F. Lopez-de-Silanes and A. Shleifer. 2003. Courts. Quarterly Journal of Economics 118: 453-517.

Everitt, B.S. 1994. Statistical methods for medical investigations. Second ed. Wiley and Sons, New York.

Ellison, D.L. 2004. Politics and the Environment in Central Europe. Paper presented at the 2004 Conference of Europeanists. "Europe and the World: Integration, Interdependence, Exceptionalism." March $11-13^{\text {th }}$, Chicago, USA.

Fidalgo, A.M., G.J. Mellenberg and J. Muniz. 2000. Effects of Amount of DIF, Test Length, and Purification Type on Robustness and Power of Mantel-Haenszel Procedures. Methods of Psychological Research 5: 43-53.

Fisher, R.A. 1935. The Logic of Inductive Inference. Journal of the Royal Statistical Society 98: 39-82.

Friedman, M. 1937. The Use of Ranks to Avoid the Assumption of Normality Implicit in the Analysis of Variance. Journal of the American Statistical Association 32: 675-701.

Geisser, S. 1963. Multivariate Analysis of Variance for a Special Covariance Case. Journal of the American Statistical Association 58: 660-669.

Glass, G.V., P.D. Peckham and J.R. Sanders. 1972. Consequences of Failure to Meet Assumptions Underlying the Fixed Effects Analyses of Variance and Covariance. Review of Educational Research, 42 (3): 237-289.

Grodzinska, K., B. Godzik, W. Fraczek, O. Badea, J. Oszlanyi, D. Postelnicu and Y. Shparyk. 2004. Vegetation of the selected forest stands and land use in the Carpathian Mountains. Environmental Pollution. 130: 17-32.

Harnett, D.L. and J.L. Murphy. 1986. Statistical analysis for Business and Economics. Addison-Wesley Publishing, Don Mills, ON.

Hellman, J., G. Jones, D. Kaufmann and M. Schankerman. 2000 Measuring governance, corruption, and state capture how firms and bureaucrats shape the business environment in transition economies. Policy research paper 2312. World Bank, Washington, DC. Hodges, J.L., Jr. and E.L. Lehmann. 1956. The Efficiency of Some Nonparametric Competitors of the $t$-Test. The Annals of Mathematical Statistics 27: 324-335.
Hollander, M. and D.A. Wolfe. 1973. Nonparametric Statistical Methods. John Wiley and Sons, New York.

Islam, M.Q. and M.L. Tiku. 2004. Multiple Linear Regression Model Under Nonnormality. Communications in Statistics - Theory and Methods 33: 2443-2467.

Johnson, S., J. McMillan and C. Woodruff. 2002. Courts and relational contracts. Journal of Law, Economics and Organization. 15: 221-277.

Keselman, H.J., R. Cribbie and B.D. Zumbo. 1997. Specialized tests for detecting treatment effects in the two-sample problem. Journal of Experimental Education 65: 355-366.

Kirby, K.J. and J.R. Heap. 1984. Forestry and Nature Conservation in Romania. Quarterly Journal of Forestry. 78: 145-155.

Lehmann, E.L. and H.J.M. D’Abrera. 1975. Nonparametrics. Holden-Day, Inc., San Francisco.

Levin, R.I. 1981. Statistics for management. Prentice-Hall, Englewood Cliffs.

Looney, S.W. and W.B. Stanley. 1989. Exploratory Repeated Measures Analysis for Two or More Groups: Review and Update. American Statistician 43: 220-225.

Ministerul silviculturii. 1986. Norme 5 pentru amenajarea padurilor. 1-197. ICAS Lithography, Bucharest.

Moise, N. and B.M. Strimbu. 2000. Fundamentarea gospodariri padurilor private in Romania. ICAS, Bucharest.

Murrell, P. 2003. Firms facing new institutions: transactional governance in Romania. Journal of Comparative Economics. 31: 695-714. Neter, J., M.H. Kutner, C.J. Nachtsheim and W. Wasserman. 1996. Applied linear statistical models. WCB McGraw-Hill, Boston.

Oszlanyi, J., K. Grodzinska, O. Badea and Y. Shparyk. 2004. Nature conservation in Central and Eastern Europe with a special emphasis on the Carpathian Mountains. Environmental Pollution. 130: 127-134.

Papadimitriou, D. and D. Phinnemore. 2004. Europeanization, conditionality and domestic change: The twinning exercise and administrative reform in Romania. Journal of Common Market Studies. 42: 619-639.

Rao, J.N.K., B.C. Sutradhar and K. Yue. 1993. Generalized Least Squares $F$ Test in Regression Analysis with Two-Stage Cluster Samples. Journal of the American Statistical Association 88: 1388-1391.

Rizov, M. 2004. Firm investment in transition - Evidence from Romanian manufacturing. Economics of Transition. 12: 721-746.

Romanian National Forest Administration (NFA). 2005. The public forest area. Romanian National Forest Administration. Available at http://www.rosilva.ro/index_eng.html. Accessed Feb. 27, 2005

Shapiro, S.S. and M.B. Wilk. 1965. An Analysis of Variance Test for Normality (Complete Samples). Biometrika. 52: 591-611.

Shoemaker, L.H. 2003. Multisample tests for the equality of dispersions based on quantiles. Communications in Statistics - Simulation and Computation 32: 103-112.

Shoukri, M.M. and C.A. Pause. 1999. Statistical Methods for Health Sciences. Second ed. CRC Press, Boca Raton.

Sotiropoulos, D.A., I. Neamtu and M. Stoyanova. 2003. The trajectory of post-communist welfare state development: The cases of Bulgaria and Romania. Social Policy and Administration. 37: 656-673.

Stan, L. and L. Turcescu. 2004. Politicians, intellectuals, and academic integrity in Romania. Problems of Post-Communism. 51: 12-24. Stephens, M.A. 1974. Edf Statistics for Goodness of Fit and Some Comparisons. Journal of the American Statistical Association. 69: 730-737.

Wilcoxon, F. 1945. Individual comparisons by ranking methods. Biometrics Bulletin. 1: 80-83.

World Bank. 2002. Romania-Forest Development Program. Report No. PID8602. The World Bank, Washington, USA.

Zhang, J. and D.D. Boos. 1997. Mantel-Haenszel test statistics for correlated binary data. Biometrics. 53: 1185-1198. 